\title{
Innovation in Learning Process of Adaptive Physical Education at STKIP Muhammadiyah Muara Bungo
}

\author{
Ade Marta Putra ${ }^{1}$, Atmazaki, and Ramalis Hakim² \\ ${ }^{I}$ STKIP Muhammadiyah Muara Bungo, Muara Bungo, Indonesia, ademartaputral @ gmail.com \\ ${ }^{2}$ Universitas Negeri Padang, Padang, Indonesia \\ *Corresponding author.Email: atmazaki@fbs.unp.ac.id, ramalishakim@gmail.com
}

\begin{abstract}
This study aims to determine the form of innovation carried out by the lecturer in the learning process of Adaptive Physical Education at STKIP Muhammadiyah Muara Bungo. This research is a descriptive qualitative research in which data was obtained by using documents, namely learning tools for lecturers in Adaptive Physical Education courses in the form of Syllabus, RPS, and Evaluation Tools. Besides, data was also taken using observation sheets. The object of the research was the only one lecturer who teaches the Adaptive Physical Education subject at STKIP Muhammadiyah Muara Bungo. The data was analyzed and was adjusted with the results of field observations, then both data were analyzed descriptively. The results of the study show that the lecturer has prepared complete learning instructions. In the process, the learning instructions had been innovatively modified in terms of sports equipments for children with special needs. This is considered effective in the implementation of the Adaptive Physical Education learning process as evidenced by student activities during the learning process.
\end{abstract}

\section{Keywords: Innovation, Learning Process, Adaptive Physical Education}

\section{INTRODUCTION}

Learning is a change in personality as a new pattern rather than a reaction in the form of skills, attitudes, habits, intelligence, or knowledge. Whereas instruction is a system that aims at helping students' learning process, which contains a series of events that are designed, arranged in such a way as to influence and support the internal occurrence of student learning processes.

Physical Education is a series of planned physical activities to improve someone physical abilities and skills, and to achieve physical and mental growth and development, and mature attitudes. Whereas according to Arma Abdoellah (1996), physical education is one aspect of the entire educational process of students through physical activities that are carefully designed, which are carried out consciously and programmed in an effort to improve physical and social skills and abilities and the development of intelligence[1]. physical education is a planned physical activity that has been consciously designed as an effort to improve the quality of growth, physic and mental development.

Basically, adaptive physical education is quite similar to other common physical education. Adaptive physical education is a comprehensive service delivery system and is designed to find out and solve the problems in psychomotor domain [2]. Adaptive physical education is physical activity that is modified to facilitate students with special needs to be actively participated in learning process. Adaptive and / or modification in adaptive physical education learning is intended to facilitate students with special needs, so that they have the same opportunity to participate actively and safely in such learning activities[3]. Thus the teacher must be creative to make innovations to meet those needs.

The learning strategies in Adaptive Physical Education should be mastered by students. In special schools, education provided to students with special needs is more focused on functional programs and prioritizes the talents and potential of children with various learning modification techniques.

Students with special needs have different needs one to another. Therefore, to fulfill this in adaptive physical education, the teachers must create modifications and adjustments, regarding the characteristics, learning atmosphere and the situation where the learning process takes place.

The environment to implement this subject also needs to be adjusted concerning the needs of the students themselves. It is to create a conducive learning atmosphere that can arouse enthusiasm and participation. Techniques to modify learning activities consist of position setting, time of participation and equipment settings[4]. Management of Teaching and Learning Process for Adaptive Physical Education Learning is an interaction between teacher and students about material taught in inside or outside the classroom[5]. 
This modification will likely be regarded as innovation if it has several characteristics as suggested, namely:

1) Excellence (Relative Advantage), is an innovation which is considered better or superior than what has been existed. This can be measured in several aspects, such as economics, social prestige, comfort, and relative satisfaction.

2) Compability, that is the level at which the innovation is considered consistent with prevailing values, past experience, and the needs of the adopters. For example if an innovation or a new idea is not in accordance with the prevailing values and norms, the innovation cannot be easily adopted.

3) Complexity, that is the level at which innovation is considered as something that is difficult to understand and use.

4) Triability, that is the level at which an innovation can be tested to a certain extent. An innovation can be tested in real settings, generally it will be adopted faster. So, in order to be quickly adopted, an innovation must be able to express excellence.

5) Ability to be observed, that is the level at which the results of an innovation can be seen by others.

Regarding the needs to modify the learning through specific techniques, a lecture should create lots of innovation to promote the success of learning. Thus, this research was conducted to find out how the innovation had been done by lecturers in the Adaptive Physical Education at STKIP Muhammadiyah Muara Bungo.

\section{METHODOLOGY}

This study was a qualitative case study which was conducted to collect data as an effort to comprehend how the innovation was carried out in the learning process. The study was conducted at STKIP Muhammadiyah Muara Bungo. The subject of this study was the Adaptive Physical Education lecturer at STKIP Muhammadiyah Muara Bungo.

Document analysis was used in this study. The documents were taken from lecturer's learning instruction including syllabus, Semester Plan, evaluation / assessment and a list of student grades. In addition to strengthen the data, the researcher also observed the teacher using an observation sheet. Data collected from documents were then analyzed using the checklist. The researcher checked the availability of learning devices and the learning process based on: (1) Reviewing curriculum and learning tools, (2) Learning Strategies, and (3) Learning evaluation systems.

The next step was to compare the results of those two data and describe the results in a table.

\section{RESULT AND DISCUSSION}

\section{RESULT}

The following are the result of the study:

1.1.1 Curriculum and learning instructions for Adaptive Physical Education Learning.

Table 1: Curriculum and Learning Instruction.

\begin{tabular}{|c|c|c|c|}
\hline No & Indicator & Document & Observation \\
\hline 1 & $\begin{array}{lr}\text { Curriculum and } \\
\text { syllabus are } \\
\text { available as learning } \\
\text { guidelines }\end{array}$ & Available & Available \\
\hline 2 & $\begin{array}{l}\text { The lecturer prepares } \\
\text { the syllabus and RPS } \\
\text { for each subject }\end{array}$ & Checked & Checked \\
\hline 3 & $\begin{array}{lr}\text { The lecturer prepares } \\
\text { effective r and } \\
\text { efficient learning } \\
\text { media }\end{array}$ & Checked & Checked \\
\hline 4 & $\begin{array}{lr}\text { Lecturers } & \text { involve } \\
\text { students in using } \\
\text { media }\end{array}$ & Involving & Involving \\
\hline 5 & $\begin{array}{l}\text { Lecturer mastery of } \\
\text { learning material }\end{array}$ & Mastered & Mastered \\
\hline 6 & $\begin{array}{l}\text { The lecturer uses } \\
\text { several reading } \\
\text { references }\end{array}$ & $\begin{array}{l}\text { Only one } \\
\text { used }\end{array}$ & Used \\
\hline 7 & $\begin{array}{l}\text { Class atmosphere } \\
\text { when the learning } \\
\text { process takes place }\end{array}$ & Active & Active \\
\hline 8 & $\begin{array}{l}\text { Lecturers prepare } \\
\text { LKS to spur student } \\
\text { activities }\end{array}$ & Prepared & Prepared \\
\hline 9 & $\begin{array}{l}\text { The lecturer prepares } \\
\text { an evaluation tool } \\
\text { equipped with an } \\
\text { answer key. }\end{array}$ & Prepared & Prepared \\
\hline 10 & $\begin{array}{l}\text { Evaluation tools are } \\
\text { prepared based on } \\
\text { basic competencies }\end{array}$ & Yes & Yes \\
\hline
\end{tabular}

The lecturer prepared the syllabus, RPS and also prepares learning media for students. In the learning process students are also included in the provision of media, even students are taught to modify the media that will be used in learning.

\subsubsection{Learning Strategies for Adaptive Physical Education.}

Table 2. Learning Strategies.

\begin{tabular}{|l|l|l|l|}
\hline No & Indicator & $\begin{array}{l}\text { Documen } \\
\mathrm{t}\end{array}$ & $\begin{array}{l}\text { Observa } \\
\text { tion }\end{array}$ \\
\hline 1 & $\begin{array}{l}\text { Lecturers do apperception } \\
\text { to open learning activities }\end{array}$ & Yes & yes \\
\hline 2 & $\begin{array}{l}\text { Lecturers apply } \\
\text { meaningful learning } \\
\text { theories in the learning } \\
\text { process }\end{array}$ & Yes & Yes \\
\hline
\end{tabular}




\begin{tabular}{|c|c|c|c|}
\hline 3 & $\begin{array}{l}\text { Lecturers use learning } \\
\text { methods that vary in } \\
\text { material explanation }\end{array}$ & Yes & Yes \\
\hline 4 & $\begin{array}{l}\text { Lecturer knows students } \\
\text { in class }\end{array}$ & Yes & Yes \\
\hline 5 & $\begin{array}{l}\text { Lecturers overcome } \\
\text { student learning } \\
\text { difficulties }\end{array}$ & Yes & Yes \\
\hline 6 & $\begin{array}{l}\text { Harmony of Lecturer and } \\
\text { Student Relations }\end{array}$ & $\begin{array}{l}\text { Harmo- } \\
\text { nious }\end{array}$ & $\begin{array}{l}\text { Harmo- } \\
\text { nious }\end{array}$ \\
\hline 7 & $\begin{array}{l}\text { Lecturers use learning } \\
\text { models that are suitable } \\
\text { for learning objectives }\end{array}$ & Yes & Yes \\
\hline 8 & $\begin{array}{l}\text { Students gain useful } \\
\text { learning experiences with } \\
\text { the model implemented }\end{array}$ & Yes & Yes \\
\hline 9 & $\begin{array}{l}\text { Lecturers motivate } \\
\text { students to be active in } \\
\text { the learning process in } \\
\text { class }\end{array}$ & Yes & Yes \\
\hline 10 & $\begin{array}{l}\text { Lecturers act as } \\
\text { facilitators as long as } \\
\text { students are active in } \\
\text { class }\end{array}$ & Yes & Yes \\
\hline 11 & $\begin{array}{l}\text { Lecturers act as } \\
\text { evaluators as long as } \\
\text { students are active in } \\
\text { class }\end{array}$ & Yes & Yes \\
\hline 12 & $\begin{array}{l}\text { Lecturers act as } \\
\text { mediators as long as } \\
\text { students are active in } \\
\text { class }\end{array}$ & Yes & Yes \\
\hline
\end{tabular}

Based on the results of the study, it is known that lecturers at the STKIP Muhammadiyah Muara Bungo Lecturer did apperception to open learning activities so that students are motivated in the teaching process Lecturers apply meaningful learning theory in the learning process so that students understand more about the material provided by lecturers. He also used various learning methods to explain materials so that students did not get bored and experienced useful learning with the model implemented.

\subsubsection{Learning evaluation system in Muara Bungo STKIP Muhammadiyah}

Table 3. Evaluation System.

\begin{tabular}{|l|l|l|l|}
\hline No & Indicator & Document & $\begin{array}{l}\text { Observati } \\
\text { on }\end{array}$ \\
\hline 1 & $\begin{array}{l}\text { Lecturers provide } \\
\text { complete evaluation } \\
\text { tools (cognitive, } \\
\text { psychomotor, affective) }\end{array}$ & Yes & Yes \\
\hline 2 & $\begin{array}{l}\text { Lecturers carry out } \\
\text { evaluations based on the } \\
\text { demands of basic } \\
\text { competencies }\end{array}$ & Yes & Yes \\
\hline 3 & $\begin{array}{l}\text { Indicators of success of } \\
\text { evaluation are available }\end{array}$ & Yes & Yes \\
\hline
\end{tabular}

\begin{tabular}{|l|l|l|l|}
\hline 4 & $\begin{array}{l}\text { Use various methods of } \\
\text { evaluation (writing, } \\
\text { oral, product, portfolio, } \\
\text { and performance) }\end{array}$ & Yes & $\begin{array}{l}\text { Yes oral, } \\
\text { writing, } \\
\text { and } \\
\text { performa } \\
\text { nce }\end{array}$ \\
\hline 5 & $\begin{array}{l}\text { Guidelines (key, rubril } \\
\text { and outline of answers) } \\
\text { are available for each } \\
\text { type of evaluation }\end{array}$ & Yes & Yes \\
\hline 6 & $\begin{array}{l}\text { Lecturers conduct } \\
\text { evaluation analysis to } \\
\text { improve learning }\end{array}$ & Yes & Yes \\
\hline 7 & $\begin{array}{l}\text { The lecturer devised a } \\
\text { follow-up plan for the } \\
\text { evaluation results }\end{array}$ & Yes & Yes \\
\hline
\end{tabular}

Based on the results shown in the table above, in the evaluation system section, the lecturer had implemented it fairly good. The lecturer successfully fulfilled all indicators in the learning evaluation system. Moreover, there is no difference between the results of the document analysis and observation result.

\section{DISCUSSION}

Innovation is needed in the world of learning. In doing innovations, we will likely be able to create learning environments that are fun, exciting, dynamic, full of enthusiasm, and full of challenges. Such learning atmosphere can facilitate students in obtaining knowledge and teachers can also instill essential noble values for students to achieve learning goals. Mastery of material managed and displayed professionally, from the heart and without coercion, logically, and pleasantly, and combined with a personal emotional approach to students will make the learning process meaningful. In addition, learning must also be varied by creating a new learning method or, in other words, innovation.

It is not easy to implement Adaptive Physical Education for there are many learning techniques and strategies that the students should be familiar with. On top of this, the learning given to special needs students is more focused on functional programs and prioritizes the talents and potential of the children. For example, sport-potentialchildren will be fully developed in sports classes. In this case, adaptive physical education plays an important role in meeting the needs of those students.

The needs of the students may be different one to another. One may need modification in the place and area of learning, while other may need modifications to the tools used in the learning activities. Therefore, to meet the needs of special needs students in adaptive physical education, the teachers must modify and adjust regarding on what the students need, especially the characteristics (behavior) related to the atmosphere and conditions where the learning will be carried out. Thus, a prospective teacher must understand the complexity that exists in each student who has these special needs. [3]The factors that need to be modified and adjusted by teachers as efforts to 
improve the ability of students with special needs are as follows:
a. Language usage
b. Make concrete concepts
c. Make a sequence of tasks
d. Availability of study time
e. Multisensory approach

In this study, the innovations found were (1) learning and evaluation tools used by the lecturers are in accordance with the curriculum. This is one of the most decisive factors in the success of the learning process, that before the teacher teaches (preparation stage), a teacher is expected to prepare the material to be taught, prepare teaching aids / tools to be used, prepare questions and direction to encourage students to actively learn, learn about the condition of students, understand the weaknesses and strengths of students, and learn the students' initial knowledge, (2) in the learning process starting from the preparation stage to the evaluation phase, it is also in accordance with the syllabus and Semester Plan, in addition, (3) the lecturer has also prepared learning media as an effective and efficient learning tool in learning. It can be seen from the activity of students during the learning process.

Learning innovations carried out by Adaptive Physical Education Lecturer at STKIP Muhammadiayah Muara Bungo have also fulfilled the characteristics of innovation, namely:

1. Excellence rate, that an innovation is considered better or superior than ever. This can be measured in several aspects, such as the economy, social prestige, comfort, and relative satisfaction of STKIP Muhammadiyah Muara Bungo students in the process of learning Adaptive Physical Education.

2. Compatibility, this can be seen from the implementation of learning strategies which are consistent with prevailing values, past experience, and the needs of adopters.

3. Complexity, learning strategies used by Adaptive Physical Education Lecturer Muhammadiyah STKIP Muara Bungo. of course not just can be easily used, it requires expertise and ability.

\section{CONCLUSION}

Based on the results and discussion in this study, the researchers concluded several things as follows:

1. The learning process of Adaptive Physical Education Muhammadiyah STKIP in Muara Bungo has been going well, where the teacher has prepared complete learning instructions before carrying out learning and teaching activities in the classroom. The instructions are in the form of syllabus, semester plan, media devices and evaluation tools.

2. In learning process, the lecturers have made an innovation in the form of learning strategies, here the teacher carries out a cooperative strategy.
3. At the end of each lesson, the teacher always conducts an evaluation in which the evaluation is carried out to measure up to where students can understand the material that has been given. The evaluation includes the cognitive, psychological, and affective abilities of students.

\section{REFERENCES}

[1] Arma Abdoellah. "Pendidikan Jasmani Adaptif". Jakarta: Dikti Depdikbud. 1996, pp 73-83.

[2] Yani \& Asep. "Pendidikan Jasmani Adaptif bagi Anak Berkebutuhan Khusus”. Jakarta: Luxima. 2013, pp 45-50.

[3] Direktorat Pemb. Pend. Khusus dan Layanan Khusus Pend. Dasar. "Pedoman Penyelenggaraan Program Penjas Adaptif bagi Peserta Didik Berkebutuhan Khusus di Sekolah Inklusi”. Jakarta: Dikjen Pend. Dasar Kemendikbud. 2013, pp 23-55.

[4] Beltasar Tarigan. "Pendidikan Jasmani Adaptif". Bandung: FPOK UPI. 2008, pp 13-34.

[5] Jamil Suprihatiningrum. "Strategi Pembelajaran: Teori \& Aplikasi”. Yogyakarta: AR-RUZZ MEDIA. 2013.pp 10-15 